\title{
Towards a quasi-complete reconstruction of past atmospheric aerosol load and composition (organic and inorganic) over Europe since 1920 inferred from Alpine ice cores
}

\author{
S. Preunkert and M. Legrand \\ CNRS/UJF - Grenoble 1, Laboratoire de Glaciologie et Géophysique de l'Environnement (LGGE), UMR5183, Grenoble, \\ 38041, France
}

Correspondence to: S. Preunkert (preunkert@lgge.obs.ujf-grenoble.fr)

Received: 10 February 2013 - Published in Clim. Past Discuss.: 26 February 2013

Revised: 11 May 2013 - Accepted: 30 May 2013 - Published: 3 July 2013

\begin{abstract}
Seasonally resolved chemical ice core records available from the Col du Dôme glacier ( $4250 \mathrm{~m}$ elevation, French Alps), are here used to reconstruct past aerosol load and composition of the free European troposphere from before World War II to present. Available ice core records include inorganic $\left(\mathrm{Na}^{+}, \mathrm{Ca}^{2+}, \mathrm{NH}_{4}^{+}, \mathrm{Cl}^{-}, \mathrm{NO}_{3}^{-}\right.$, and $\left.\mathrm{SO}_{4}^{2-}\right)$ and organic (carboxylates, $\mathrm{HCHO}$, humic-like substances, dissolved organic carbon, water-insoluble organic carbon, and black carbon) compounds and fractions that permit reconstructing the key aerosol components and their changes over the past. It is shown that the atmospheric load of submicron aerosol has been increased by a factor of 3 from the 1921-1951 to 1971-1988 years, mainly as a result of a large increase of sulfate (a factor of 5), ammonium and watersoluble organic aerosol (a factor of 3). Thus, not only growing anthropogenic emissions of sulfur dioxide and ammonia have caused the enhancement of the atmospheric aerosol load but also biogenic emissions producing water-soluble organic aerosol. This unexpected change of biospheric source of organic aerosol after 1950 needs to be considered and further investigated in scenarios dealing with climate forcing by atmospheric aerosol.
\end{abstract}

\section{Introduction}

A reconstruction of our changing atmosphere from the present-day polluted atmosphere back to preindustrial times and an evaluation of the subsequent radiative impact are strongly needed to improve our understanding of present and future climate. From this point of view, the knowledge of past atmospheric changes in aerosol load and composition are required to predict future climate, particularly at regional scales.

The decrease of $\mathrm{SO}_{2}$ emissions resulting from an improvement in the quality of fuel and emission abatements over the three last decades has led to a decrease of sulfate levels in the atmosphere over large industrialized regions, including Europe (Mylona, 1996). In the present-day European atmosphere, organic matter is recognized to be a major constituent of aerosol (Putaud et al., 2004; Pio et al., 2007). There are however still major deficits in knowledge with respect to its sources. For instance, the relative contribution of natural and anthropogenic sources to the present-day organic carbon (OC) aerosol as well as the variability of natural sources over the past are not well known. That contrasts with inorganic aerosol like sulfate for which source apportionment (natural versus anthropogenic) has been established and past anthropogenic emission inventories exist (see Mylona, 1996, for Europe). The study of chemical impurities trapped in solid precipitation accumulated over the past on cold glaciers represents a unique and powerful way to reconstruct our changing atmosphere from the preindustrial era to present day (see Legrand and Mayewski, 1997, for a review).

To our knowledge, the most extended array of chemical species investigated in ice deposited since the beginning of the 20th century was obtained in ice cores extracted at the Col du Dôme (CDD, $4250 \mathrm{~m}$ a.s.l.) glacier site located in the Mount Blanc massif (French Alps). Investigations included inorganic ions $\left(\mathrm{F}^{-}, \mathrm{Cl}^{-}, \mathrm{NO}_{3}^{-}, \mathrm{SO}_{4}^{2-}, \mathrm{Na}^{+}, \mathrm{NH}_{4}^{+}, \mathrm{K}^{+}\right.$, 
$\mathrm{Mg}^{2+}$, and $\left.\mathrm{Ca}^{2+}\right)$ and short-chain $\left(\mathrm{C}_{1}-\mathrm{C}_{5}\right)$ mono- and dicarboxylates. The organic fraction was also documented along these ice cores for its dissolved organic (DOC) fraction, formaldehyde (HCHO), and humic-like substances (HULIS) (see Legrand et al., 2013, and references therein), which were investigated for the first time in ice. The CDD ice cores were shown to record quite well the seasonal cycle of chemical species in contrast to those extracted at other Alpine sites, like Colle Gnifetti (4450 m a.s.l., Swiss Alps), where, to the benefit of an extended archived time period, the preservation of winter layers is often incomplete even near the surface (Preunkert et al., 2000; Wagenbach et al., 2012). Although a rapid annual ice layer thinning appears with depth in the CDD ice cores, they possess a good preservation of seasonal variations back to 1925 in relation with a high snow accumulation at the surface ( $3 \mathrm{~m}$ water equivalent). This large snow accumulation also minimized diffusional and depositional perturbations of the record of gases like nitric acid (Preunkert et al., 2003) or formic and acetic acids (Legrand et al., 2003). Finally, it is important to emphasize that near the CDD drill site stands the Vallot observatory ( $4360 \mathrm{~m}$ a.s.l., $400 \mathrm{~m}$ southeast of the Col du Dôme drill site), where several atmospheric sampling campaigns were conducted (Preunkert et al., 2002, 2007; Legrand et al., 2005). Atmospheric information available here is very useful for inverting chemical ice core records in terms of past atmospheric concentrations of water-soluble gases and aerosols.

In this paper, among the array of chemical (organic and inorganic) ice core records available from the high-elevation CDD Alpine site, we select and use those that contain relevant aerosol information in order to reconstruct the past atmospheric change of aerosol load and composition over Europe from 1920 to the recent decades. That permits reconstructing the mass concentrations of the key aerosol components, such as nitrogen- and sulfur-related aerosol, carbonaceous aerosol, sea salt and mineral dust, and their changes over the past.

\section{Ice core dating, sampling and analyses}

\subsection{Dating}

Since 1994, three ice cores have been drilled close to bedrock at virtually the same place at the Col du Dôme glacier site ( $4250 \mathrm{~m}$ a.s.1.), located near the Mont Blanc summit. Whereas the C10 ice core (126 m long) and its twin (C11, $140 \mathrm{~m}$ long, drilled less than $50 \mathrm{~m}$ away from the $\mathrm{C} 10)$ were extracted in 1994, the CDK ice core (124 m long) was drilled in 2004.

The overall glacio-chemical setting of the CDD site and the accurate dating of its snow and ice layers are described in Preunkert et al. (2000). In brief, the dating was first established by counting annual layers along the ammonium C10 profile and the identification of the 1963 tritium or
${ }^{137} \mathrm{Cs}$ bomb peak. As detailed in Preunkert et al. (2000) we could identify also the dust horizons of 1977, 1947, and 1936 within the Col du Dôme ice. The dating of $\mathrm{C} 10$ was estimated to be better than $\pm 2 \mathrm{yr}$ after $1954, \pm 4 \mathrm{yr}$ in the 1940 s, and $\pm 5 \mathrm{yr}$ around 1920 . Based on examination of the ammonium profile, each annual layer was divided into two parts corresponding to winter and summer snow deposition following the procedure detailed in Preunkert et al. (2000). From that, the individual means of summer and winter half years were calculated for all chemical species.

Pieces of ice from the $\mathrm{C} 11$ core were used for some discontinuous chemical investigations. Its dating was established by scaling down the dating established on the $\mathrm{C} 10$ core (see Fig. 1) by checking the time horizons of 1954 and 1963 in the two ice cores (Legrand et al., 2007a). As seen in Fig. 2, the $\mathrm{C} 11$ ice core summer half-year means of sulfate and nitrate are in very good agreement with the $\mathrm{C} 10$ ones over the 1925-1994 period.

The dating of the more recently drilled CDK ice core was more complicated to establish as detailed in Legrand et al. (2013). The dating was attempted by counting annual layers along the ammonium profile as done for $\mathrm{C} 10$ (see also Fig. 1). However, between 65.5 and $67.5 \mathrm{~m}$ water equivalent (mwe) the ammonium seasonal cycle vanishes and sulfate and nitrate exhibit unexpected low values. Below 67.5 mwe the ammonium seasonal signature recovers and remains easily detectable down to 91.5 mwe. Tritium measurements revealed that ice layers corresponding to the main bomb peak were definitely missing in this core. It was concluded that a crevasse might have developed upstream of the borehole, having caused a hiatus in the CDK ice core stratigraphy. As suggested by tritium values, the CDK ice located below 67.5 mwe was deposited prior to 1954 . The dating for the 67.5-91.5 mwe part of the CDK core was established by comparing the stratigraphies of various species (ammonium, nitrate, sulfate, calcium, and others) with those of the C10 core. From that, Legrand et al. (2013) concluded that the CDK layers deposited between 86.0 and 67.5 mwe cover the 1925-1954 time period with an uncertainty of $\pm 4 \mathrm{yr}$. As seen in Fig. 2, the derived CDK ice core summer half-year means of sulfate and nitrate appear again in very good agreement with the C10 ones over the 1925-1994 period.

\subsection{Sampling and analysis}

For each species of concern, details on sampling and working conditions applied for analysis can be found in the references reported in Table 1. Depending on measurements, ice samples were cleaned mechanically in a cold room or by washing them in ultrapure water. For determination of ions and $\mathrm{HCHO}$, pieces of ice were cleaned under a clean air bench located in a cold room $\left(-15^{\circ} \mathrm{C}\right)$ using an adapted and precleaned electric plane tool mounted to be used as a sort of bench plane over which the ice is slid. For HULIS measurements, ice was decontaminated in a clean room by washing 
Table 1. Summary of chemical species (or fractions) that were investigated on a continuous (or quasi-continuous) and seasonally resolved basis along CDD ice cores, its physical state in the atmosphere, and references of the respective original studies. For a species $X$, the $\alpha$ value corresponds to the estimated ratio of $X$ to calcium mass in Saharan dust (Preunkert, 2001). They were used to correct concentrations from Saharan dust inputs by using calcium $\left([X]_{\text {corrected }}=[X]-\alpha\left[\mathrm{Ca}^{2+}\right]\right)$.

\begin{tabular}{llll}
\hline Species in ice & Atmospheric phases & $\alpha$ & References \\
\hline $\mathrm{F}^{-}$ & Gas (HF)/aerosol & $2 \times 10^{-3}$ & Preunkert et al. (2001a) \\
$\mathrm{Cl}^{-}$ & Aerosol/gas (HCl) & 0.06 & Legrand et al. (2002) \\
$\mathrm{NO}_{3}^{-}$ & Gas $(\mathrm{HNO}$ )/aerosol & 0.01 & Preunkert et al. (2003) \\
$\mathrm{SO}_{4}^{2-}$ & Aerosol & 0.59 & Preunkert et al. (2001b) \\
$\mathrm{NH}_{4}^{+}$ & Aerosol & 0.03 & Fagerli et al. (2007) \\
$\mathrm{Na}^{+}, \mathrm{K}^{+}, \mathrm{Mg}^{2+}, \mathrm{Ca}^{2+}$ & Aerosol & $0.03-0.07$ & Legrand et al. (2002) \\
$\left.\mathrm{Monocarboxylates}_{(\mathrm{HCO}}^{-}, \mathrm{CH}_{3} \mathrm{CO}_{2}^{-}\right)$ & Gas (HCOOH, & $0.01-0.02$ & Legrand et al. (2003) \\
Dicarboxylates $\left(\mathrm{C}_{2}-\mathrm{C}_{5}\right)$ & CH & Aerosol & \\
$\mathrm{HULIS}$ & Aerosol & 0.01 & Legrand et al. (2013) \\
$\mathrm{HCHO}$ & Gas & 0 & Guilhermet et al. (2013) \\
DOC & Gas/aerosol & 0 & Legrand et al. (2013) \\
EC/WinOC & Aerosol & 0 & Legrand et al. (2013) \\
\hline
\end{tabular}

a Only discontinuous sampling (see Sect. 4.2).

it in three successive baths of ultrapure water produced by a Maxima HPLC system (Elga). Among all measurements, the one of DOC was found to be the most sensitive to contamination. To remove the contaminated outer part of ice pieces prior to DOC analysis, a special glass device was designed in which pieces of ice are cleaned with ultrapure water (Elga) and kept melting (Preunkert et al., 2011). During the ice melting, an inert gas atmosphere is maintained inside the glass receptacle to prevent contact of sample with ambient air of the lab. Note that until now cleaning of samples for DOC determinations can only be applied to ice material but not to porous firn. Only ions were determined along the firn part of the cores. These samples were cleaned similarly to the ice samples with a plane. For most species, blanks of the ice decontamination procedure were found to be insignificant with respect to respective levels found in the ice cores.

For cations $\left(\mathrm{Na}^{+}, \mathrm{K}^{+}, \mathrm{Mg}^{2+}, \mathrm{Ca}^{2+}\right.$, and $\left.\mathrm{NH}_{4}^{+}\right)$, a Dionex 500 chromatograph equipped with a CS12 separator column was used. For anions, a Dionex 600 equipped with an AS11 separator column was run with a quaternary gradient of eluents $\left(\mathrm{H}_{2} \mathrm{O}, \mathrm{NaOH}\right.$ at 2.5 and $100 \mathrm{mM}$, and $\left.\mathrm{CH}_{3} \mathrm{OH}\right)$. A gradient pump system allows the determination of inorganic species $\left(\mathrm{F}^{-}, \mathrm{Cl}^{-}, \mathrm{NO}_{3}^{-}\right.$, and $\left.\mathrm{SO}_{4}^{2-}\right)$ as well as short-chain carboxylates. Investigated carboxylates included formate $\left(\mathrm{HCO}_{2}^{-}\right)$, lactate $\left(\mathrm{CH}_{3} \mathrm{CHOHCO}_{2}^{-}\right)$, acetate $\left(\mathrm{CH}_{3} \mathrm{CO}_{2}^{-}\right)$, glycolate $\left(\mathrm{CH}_{2} \mathrm{OHCO}_{2}^{-}\right)$, and glyoxylate $\left(\mathrm{CHOCO}_{2}^{-}\right)$, oxalate $\left(\mathrm{C}_{2} \mathrm{O}_{4}^{2-}\right)$, malate $\left(\mathrm{CO}_{2} \mathrm{CH}_{2} \mathrm{CHOHCO}_{2}^{2-}\right)$, malonate $\left(\mathrm{CO}_{2} \mathrm{CH}_{2} \mathrm{CO}_{2}^{2-}\right)$, succinate $\left(\mathrm{CO}_{2}\left(\mathrm{CH}_{2}\right)_{2} \mathrm{CO}_{2}^{2-}\right)$, and glutarate $\left(\mathrm{CO}_{2}\left(\mathrm{CH}_{2}\right)_{3} \mathrm{CO}_{2}^{2-}\right)$.

$\mathrm{HCHO}$ was measured by a fluorimetric method based on the liquid phase reaction of formaldehyde with acetyl acetone and a $\mathrm{CH}_{3} \mathrm{COONH}_{4}-\mathrm{CH}_{3} \mathrm{COOH}$ mixture (Hantzsch reagent). Water-soluble HULIS were extracted by using a DEAE (Diethylaminoethyl) resin and the quantification of the organic carbon content of the HULIS fraction was made with a Shimadzu TOC analyzer (Guilhermet et al., 2013). The dissolved organic content (DOC) of ice samples was determined by using a commercial Phoenix 8000 device (Teledyne Tekmar company), which was modified to allow DOC determinations at the level of a few ppbC (Preunkert et al., 2011). In brief, the liquid sample is first mixed with phosphoric acid and sparged to drive off inorganic carbon. Next, the sample is transferred to a reactor where an UV lamp together with the use of synthetic air as a carrier gas oxidizes organic carbon into $\mathrm{CO}_{2}$ hereafter quantified in a nondispersive infrared (NDIR) detector.

\section{Presentation of available data}

\subsection{Saharan dust events}

Saharan dust plumes that sometimes reach western Europe also affect the Alps and disturb the chemistry of snow deposits. Following Wagenbach et al. (1996) these events can be identified as calcium-rich alkaline snow layers. The acidity (or alkalinity) of samples can be evaluated by checking the ionic balance between anions and cations with concentrations expressed in micro-equivalents per liter, $\mu \mathrm{EqL}^{-1}$ :

$$
\begin{aligned}
{\left[\mathrm{H}^{+}\right] } & =\left(\left[\mathrm{F}^{-}\right]+\left[\mathrm{Cl}^{-}\right]+\left[\mathrm{NO}_{3}^{-}\right]+\left[\mathrm{SO}_{4}^{2-}\right]+\left[\mathrm{MonoAc}^{-}\right]\right. \\
& \left.+\left[\mathrm{DiAc}^{2-}\right]\right)-\left(\left[\mathrm{Na}^{+}\right]+\left[\mathrm{K}^{+}\right]+\left[\mathrm{Mg}^{2+}\right]+\left[\mathrm{Ca}^{2+}\right]\right. \\
& \left.+\left[\mathrm{NH}_{4}^{+}\right]\right)
\end{aligned}
$$

with 

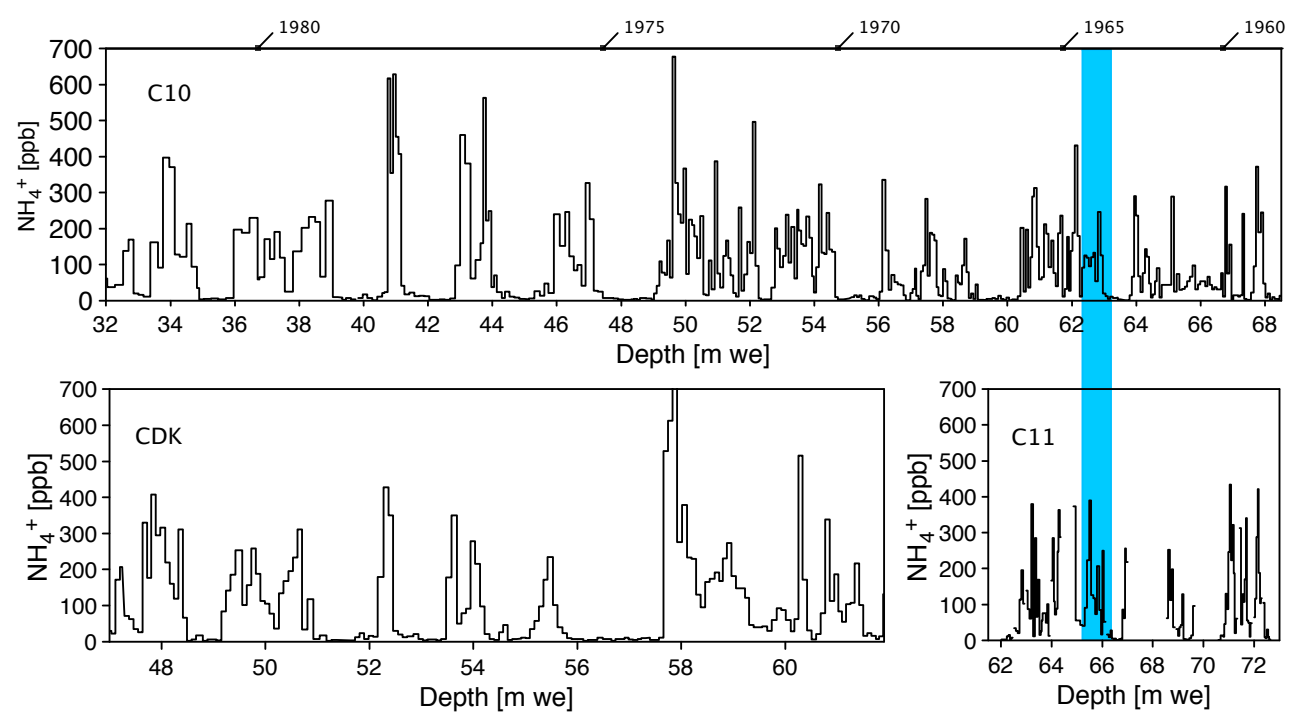

Fig. 1. $\mathrm{NH}_{4}^{+}$raw data from the $\mathrm{C} 10$ (top), $\mathrm{CDK}$ (bottom left) and $\mathrm{C} 11$ (bottom right) ice cores, illustrating the similar pattern of ion depth profiles seen in the Col du Dôme ice cores. The blue zone refers to the depths corresponding to the bomb test maximum horizon of 1963 detected in the $\mathrm{C} 10$ and $\mathrm{C} 11$ ice cores.

$$
\begin{aligned}
{\left[\mathrm{MonoAc}^{-}\right] } & =\left[\mathrm{HCO}_{2}^{-}\right]+\left[\mathrm{CH}_{3} \mathrm{CHOHCO}_{2}^{-}\right] \\
& +\left[\mathrm{CH}_{3} \mathrm{CO}_{2}^{-}\right]+\left[\mathrm{CH}_{2} \mathrm{OHCO}_{2}^{-}\right] \\
& +\left[\mathrm{CHOCO}_{2}^{-}\right]
\end{aligned}
$$

and

$$
\begin{aligned}
{\left[\mathrm{DiAc}^{2-}\right] } & =\left[\mathrm{C}_{2} \mathrm{O}_{4}^{2-}\right]+\left[\mathrm{CO}_{2} \mathrm{CH}_{2} \mathrm{CHOHCO}_{2}^{2-}\right] \\
& +\left[\mathrm{CO}_{2} \mathrm{CH}_{2} \mathrm{CO}_{2}^{2-}\right]+\left[\mathrm{CO}_{2}\left(\mathrm{CH}_{2}\right)_{2} \mathrm{CO}_{2}^{2-}\right] \\
& +\left[\mathrm{CO}_{2}\left(\mathrm{CH}_{2}\right)_{3} \mathrm{CO}_{2}^{2-}\right]
\end{aligned}
$$

As detailed by Preunkert et al. (2001a), summer samples containing more than $100 \mathrm{ng} \mathrm{g}^{-1}$ of calcium and lying below the $25 \%$ quartile of a robust spline (Bloomfield and Steiger, 1983) through the raw acidity profile are considered as significantly affected by Saharan dust input. In addition, over the last 4 decades (after 1960), because of enhanced acidity, samples containing Saharan dust input can remain acidic (Maupetit and Delmas, 1994). Such samples were characterized by Maupetit and Delmas (1994) as having typical sulfate-to-calcium and nitrate-to-calcium weight ratios close to 2.6 and 1.2 , respectively. Winter samples, containing more than $20 \mathrm{ng} \mathrm{g}^{-1}$ of calcium and having an alkalinity lying below the $25 \%$ quartile of the robust spline, were also considered as influenced by Saharan dust input. With that, 98 summer (on a total of 762 samples) and 4 winter (on a total of 337 samples) samples are suspected to be influenced by Saharan dust.

To date, along the C10 ice core, Preunkert et al. (2001a) have identified 98 summer (on a total of 762 samples) and 4 winter (on a total of 337 samples) samples as suspected to be influenced by Saharan dust. The ionic budget of a CDK snow layer containing Saharan dust is reported in Fig. 3 along with the one of its averaged adjacent summer layers. It can be seen that, in addition to the large enhancement of the alkalinity and of the calcium content likely related to the large presence of carbonates in Saharan dust, the level of several other ions is significantly enhanced (e.g., sulfate and monocarboxylates). In Fig. 4 we compare the summer half-year CDK means of calcium calculated when all data are considered and when individual samples suspected to be influenced by a Saharan dust input have been discarded. It can be seen that these events significantly influence the calcium level ( $28 \%$ on average) with an increasing contribution over the recent decades (from $18 \%$ between 1920 and 1930 to $33 \%$ from 1990 to 2004). Note such a changing Saharan dust contribution remains difficult to discuss on the basis of one or a few ice records given the very sporadic character of the corresponding deposition.

Since the occurrence and the magnitude of these Saharan dust events have changed over time, when necessary, the long-term chemical records have to be corrected from their contribution. The procedures used to correct the different records from the Saharan dust contribution are detailed in the corresponding publications (see also $\alpha$ values reported in Table 1). Since sulfate is significantly present in Saharan dust as gypsum, Saharan dust events may influence the long-term trends of sulfate. It is found that the dust events contribute $5 \%$ on average (up to $14 \%$ in individual summers, like summer 2000) to the summer sulfate snow deposits along the CDK ice core. For nitrate, the dust contribution is lower $(1 \%$ on average, up to $4 \%$ in summer 2000). For ammonium, the third-most-abundant ion, the dust contribution remains on 


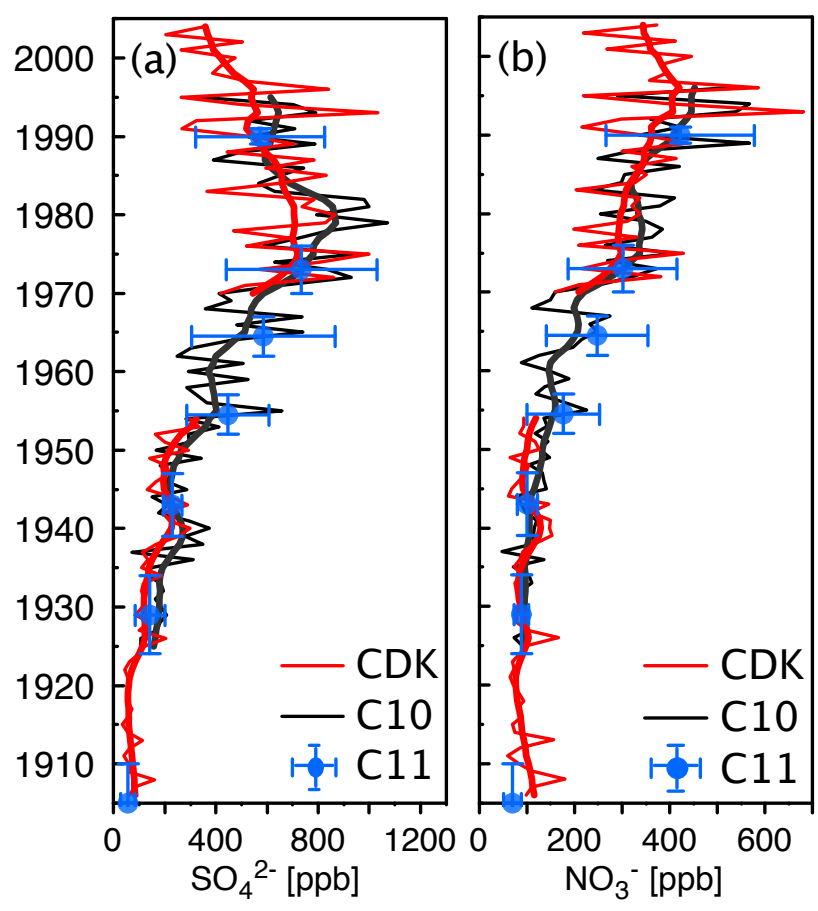

Fig. 2. Comparison of summer half-year means of sulfate and nitrate along the $\mathrm{C} 10, \mathrm{C} 11$, and CDK ice cores. For C10 and CDK, the thin solid lines refer to individual summer means and the thick solid lines to the smoothed profiles (singular spectrum analyses, time window of $5 \mathrm{yr}$ ). For $\mathrm{C} 11$, the discontinuous sampling (blue dots) is reported with vertical bars referring to the standard deviations related to sample content variability and horizontal bars to the covered time periods. C10 data are from Preunkert et al. (2001b, 2003), C11 data from Legrand et al. (2007a), and CDK data from Legrand et al. (2013). All data were corrected from the Saharan dust contribution (see Sect. 3.1). Adapted from Legrand et al. (2013).

average insignificant. Even being less abundant in Saharan dust than sulfate (see $\alpha$ values in Table 1), the dust contributions of chloride and magnesium are still significant (from 5 to $10 \%$ on average).

Although being not abundant in Saharan dust, the level of monocarboxylates shows an increase in snow layers containing Saharan dust (Fig. 3). However, as discussed by Legrand et al. (2003), these weak acids that are present in the atmosphere in the gas phase may have been remobilized after snow deposition with a preferential retention on alkaline snow layers. Finally, no evidence of a significant Saharan dust contribution was found for other organic species or fractions (HULIS, HCHO, and DOC).

\subsection{Seasonality of the snow and ice CDD chemical records}

Numerous atmospheric studies carried out at elevated sites in Europe have revealed a well-marked summer maximum of various chemical species in relation to a more efficient

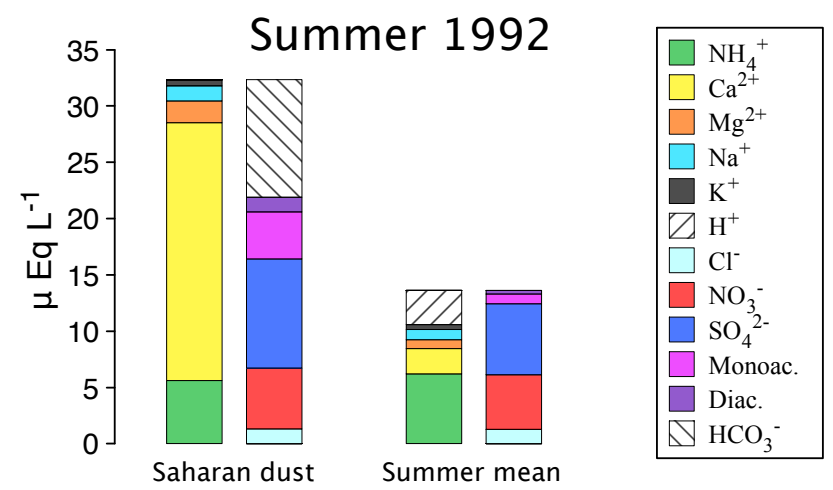

Fig. 3. Ionic content of CDK snow layers deposited during summer 1992. Left: a snow layer containing Saharan dust. Right: average over 1992 summer layers adjacent to the dust layer. Abbreviations Monoac. and Diac. stand for $\mathrm{C}_{1}-\mathrm{C}_{3}$ monocarboxylates and $\mathrm{C}_{2}-\mathrm{C}_{5}$ dicarboxylates, respectively (see Eqs. 2 and 3 in Sect. 3.1).

upward advection of air masses from the boundary layer in summer than in winter (Baltensperger et al., 1997; Kasper and Puxbaum, 1998; Pio et al., 2007; Hammer et al., 2007). This was also seen at the very high-elevation site of the Vallot observatory located near the CDD drill site (Preunkert et al., 2002; Legrand et al., 2005). Thus, the interpretation of long-term chemical records extracted from a small-scale Alpine glacier in terms of past atmospheric chemistry has to carefully consider possible changes in the surface topography and snow deposition characteristics upstream of the drill site. As shown by Preunkert et al. (2000) along the C10 core for instance, the ratio of winter to summer net snow accumulation is decreasing from 1 near the surface to 0.5 at 74 mwe. Therefore a direct examination of averaged ice concentrations without any seasonal dissection would induce a nonatmospheric effect in ice core records there. Therefore, and taking advantage of a good preservation of the seasonal signal down the length of the CDD ice cores (see Sect. 2.1), winter and summer long-term trends were examined separately in all previous CDD ice core studies.

The above-mentioned seasonal change of the air mass upward transport is associated with a geographical change of source regions impacting high-elevation Alpine sites. The sources of atmospheric aerosol that are trapped in the CDD snow layers were investigated by performing sourcereceptor calculations using the regional EMEP chemical transport model. For sulfate and ammonium, Fagerli et al. (2007) showed that Spain, Italy, France and Germany are the main contributors at the CDD site in summer, whereas in winter more European-wide and trans-Atlantic contributions were found. Note that this conclusion is an additional argument for a separated examination of summer and winter trends extracted from the CDD ice records.

Table 1 summarizes the available various seasonally resolved records covering changes from before World War II to the recent decades. Investigated chemical species are present 


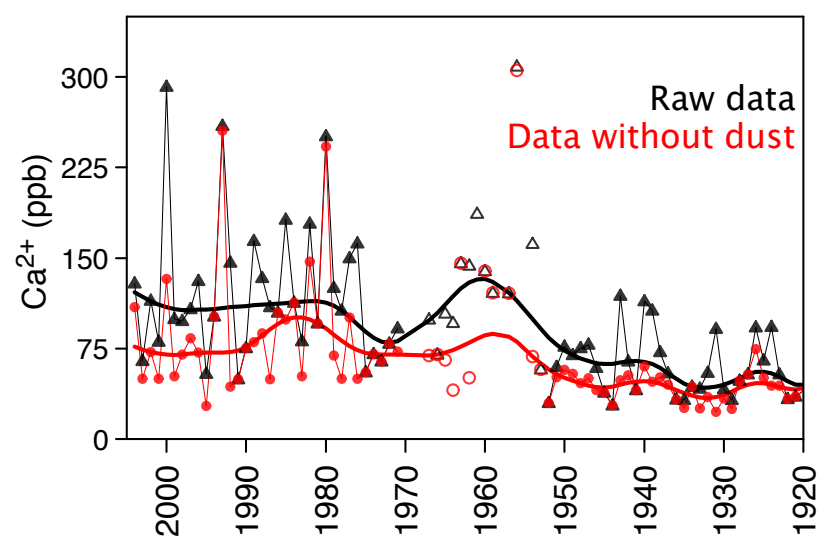

Fig. 4. Summer half-year means of calcium along the well-dated part of the CDK ice core (solid dots). The open points correspond to samples from the $\mathrm{C} 11$ ice core (see Sect. 2.1). The thick solid lines are robust spline smoothing (Bloomfield and Steiger, 1983). Black dots and lines refer to raw data, red ones to data after having discarded Saharan dust events (see Sect. 3.1).

in the atmosphere as either aerosol or gases, or both. In the following we critically review all investigated species in order to select those contributing to the atmospheric aerosol load.

\section{Snow and ice content versus atmospheric aerosol}

Among species investigated already in CDD ice cores, we select in this section those that contribute to aerosol. Their corresponding aerosol mass contributions and their changes over the past are calculated.

\subsection{Inorganics}

In the following we examine which inorganic species trapped in ice provide relevant information on past atmospheric aerosol. Sulfate and all cations are atmospheric aerosol components. Other inorganic anions are present in the atmosphere in the gas (their acidic form) and aerosol phase (Table 1).

For nitrate, the most abundant inorganic anion present in CDD ice after sulfate (see Fig. 5), the atmospheric gasaerosol partitioning is highly variable, generally in favor of aerosol (up to $50 \%$ of total nitrate) in the boundary layer compared to the free troposphere (Dibb et al., 2003). Kasper and Puxbaum (1998) reported a similar amount of nitrate in gas and aerosol phase at Sonnblick (3106 ma.s.1.) in summer, but four times less aerosol than nitric acid in winter. Except in the presence of Saharan dust particles (alkaline material) that sporadically affect Alpine sites (see Sect. 3.1), we can assume that at the remote CDD site, when present, particulate nitrate is mainly in the form of ammonium nitrate $\left(\mathrm{NH}_{4} \mathrm{NO}_{3}\right)$. This aerosol is formed when am-

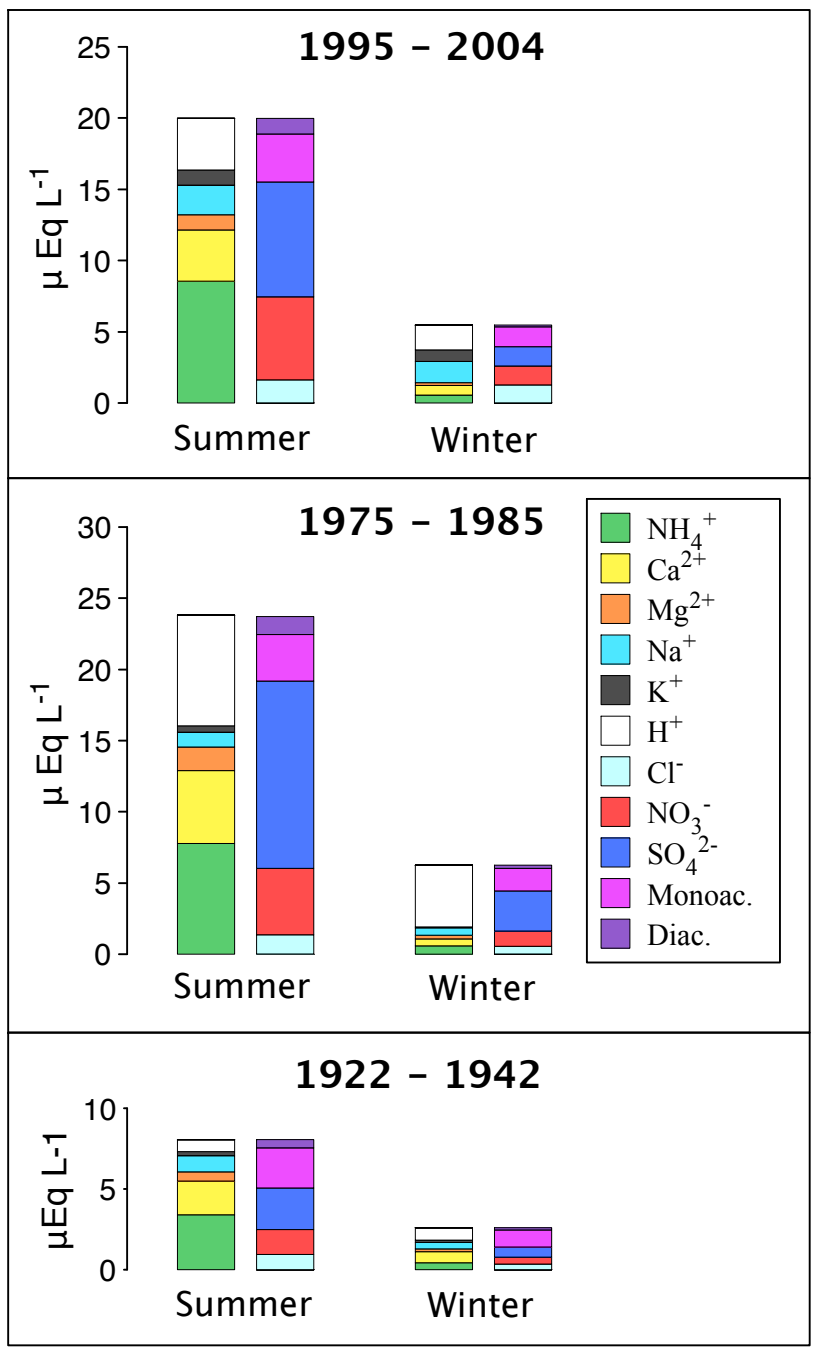

Fig. 5. Overall mean ionic composition of snow and ice layers deposited in summer (left) and winter (right) over three different time periods in the CDK core. Abbreviations Monoac. and Diac. stand for $\mathrm{C}_{1}-\mathrm{C}_{3}$ monocarboxylates and $\mathrm{C}_{2}-\mathrm{C}_{5}$ dicarboxylates, respectively (see Eqs. 2 and 3 in Sect. 3.1). Individual summer and winter half-year means were calculated after having corrected data from the contribution of Saharan dust (see details in Sect. 3.1).

monia is present in excess with respect to a full neutralization of sulfuric acid aerosol. On an equivalent basis (i.e., in $\mu \mathrm{Eq} \mathrm{m}^{-3}$ ), the mean composition of atmospheric aerosol collected on quartz filters at Vallot in summer since 1999 (detailed working conditions are reported in Preunkert al., 2002) indicates similar mean concentrations of ammonium and sulfate $\left(\left[\mathrm{NH}_{4}^{+}\right]=10.8 \mu \mathrm{Eq} \mathrm{m}{ }^{-3}\right.$ and $\left.\left[\mathrm{SO}_{4}^{2-}\right]=10.3 \mu \mathrm{Eq} \mathrm{m}{ }^{-3}\right)$. Though samplings on quartz filters are well known to lead to variable losses of $\mathrm{NH}_{4} \mathrm{NO}_{3}$ at temperatures higher than $10^{\circ} \mathrm{C}$ (Hering and Cass, 1999), the temperature of sampling filters at the Vallot observatory that remains close to zero even in summer may have minimized this negative artifact. The slope of the linear relationship between ammonium and sulfate 

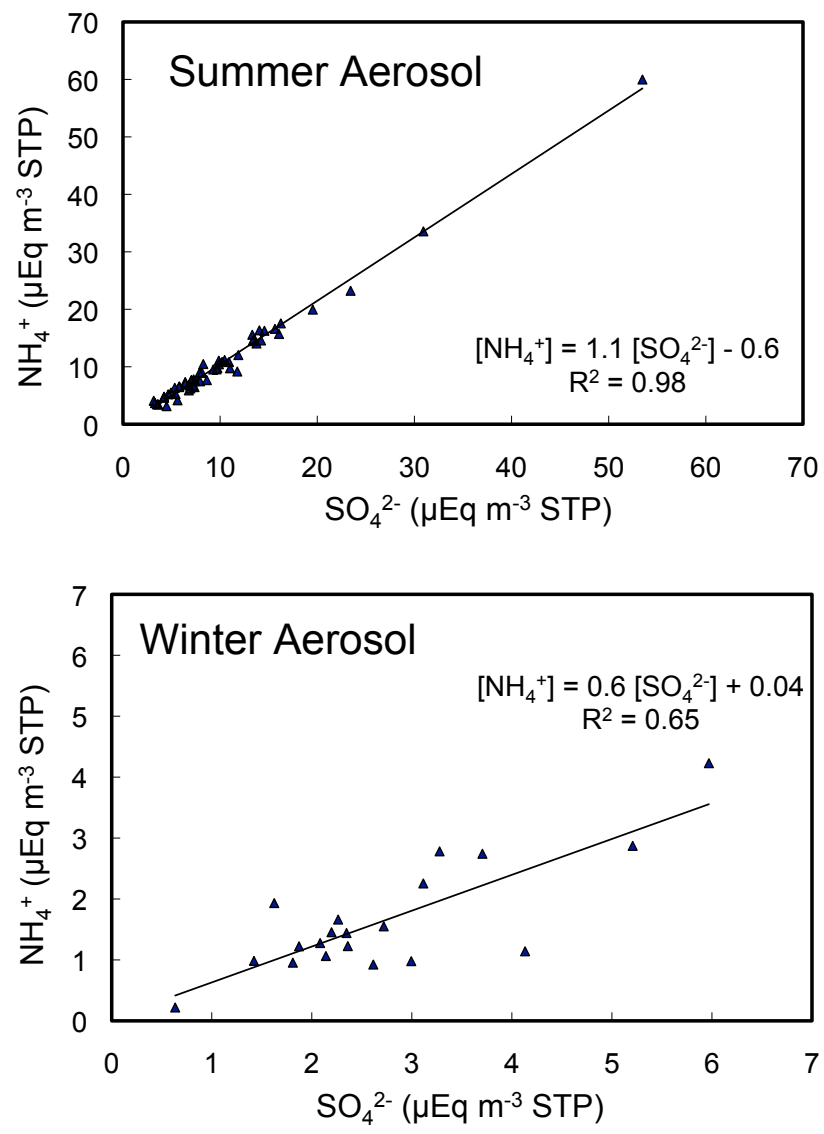

Fig. 6. Ammonium as a function of sulfate in atmospheric aerosol sampled at the Vallot observatory in summer (top) and winter (bottom) between 1999 and 2010. Concentrations are given in $\mathrm{ng} \mathrm{m}^{-3}$ STP.

concentrations close to 1.1 (Fig. 6) suggests that, in addition to $\left(\mathrm{NH}_{4}\right)_{2} \mathrm{SO}_{4}$, around $10 \%$ of ammonium are present as another chemical form (i.e., likely $\mathrm{NH}_{4} \mathrm{NO}_{3}$ ). Total nitrate collected by using both quartz and nylon filters (Preunkert et al., 2002) in summer at Vallot indicates a mean concentration of $4.5 \mu \mathrm{Eq} \mathrm{m}^{-3}$. The observed mean excess of ammonium with respect to $\left(\mathrm{NH}_{4}\right)_{2} \mathrm{SO}_{4}$ would correspond to around $1 \mu \mathrm{Eq} \mathrm{m}^{-3}$ of nitrate in the form of $\mathrm{NH}_{4} \mathrm{NO}_{3}$, the remaining part of nitrate $\left(3.5 \mu \mathrm{Eq} \mathrm{m}^{-3}\right)$ being present as gaseous nitric acid. That leads to a gas-aerosol partitioning of nitrate favoring nitric acid $\left(80 \% \mathrm{HNO}_{3}\right.$ against $20 \% \mathrm{NH}_{4} \mathrm{NO}_{3}$ aerosol). During a short summer campaign conducted at Vallot in 2004 under typical summer conditions, Preunkert et al. (2007) investigated the nitrate partitioning by sampling $\mathrm{HNO}_{3}$ on coated denuder tubes and particulate nitrate on a quartz filter mounted behind the tubes. They also found that on average around $20 \%$ of total nitrate was present in the aerosol phase.

The similar abundance of ammonium and sulfate seen in summer aerosol at Vallot since 1999 is consistent with the composition of snow deposited between 1995 and 2004 $\left(\left[\mathrm{NH}_{4}^{+}\right]=8.5 \mu \mathrm{EqL} \mathrm{L}^{-1}\right.$ and $\left[\mathrm{SO}_{4}^{2-}\right]=8.0 \mu \mathrm{EqL}^{-1}$, Fig. 5).
When $\mathrm{SO}_{2}$ emissions in western Europe reached their maximum in the 1970s (see Sect. 5), sulfate CDD snow concentrations largely exceeded ammonium ones $\left(13.2 \mu \mathrm{Eq} \mathrm{L}^{-1}\right.$ against $7.8 \mu \mathrm{EqL}^{-1}$, Fig. 5). Under these conditions sulfate would be mainly present as ammonium bisulfate, whereas ammonium nitrate would have been not produced. Note that, given the relative abundance of ammonium with respect to sulfate in summer snow deposited between 1922 and 1942 $\left(\left[\mathrm{NH}_{4}^{+}\right]=3.4 \mu \mathrm{Eq} \mathrm{L}^{-1}\right.$ and $\left[\mathrm{SO}_{4}^{2-}\right]=2.6 \mu \mathrm{EqL} \mathrm{L}^{-1}$, Fig. 5), on a total of $1.6 \mu \mathrm{EqL}^{-1}$ of nitrate, at least $0.8 \mu \mathrm{Eq} \mathrm{L}{ }^{-1}$ of nitrate would correspond to ammonium nitrate. In conclusion, at present (after 1999) the nitrate only contributes to the CDD aerosol load at a level of around $1 \mu \mathrm{Eq} \mathrm{m}^{-3}$ (i.e., $60 \mathrm{ng} \mathrm{m}^{-3}$ ). This contribution was rather similar between 1920 and 1940 but lower in the 1970s, characterized by a more acidic atmosphere related to larger $\mathrm{SO}_{2}$ emissions. In winter, whatever the time period, sulfate is always in excess with respect to $\left(\mathrm{NH}_{4}\right)_{2} \mathrm{SO}_{4}$, and a significant contribution of $\mathrm{NH}_{4} \mathrm{NO}_{3}$ to the atmospheric aerosol load at CDD is unlikely.

The most abundant halogen in CDD ice is chloride. Its budget has been discussed by Legrand et al. (2002), showing that, in addition to soil and halide aerosols, chloride also originates from $\mathrm{HCl}$ emitted by biomass burning, coal combustion and waste incineration. The presence of $\mathrm{HCl}$ in the summer atmosphere at CDD was confirmed by atmospheric measurements made with denuder tubes in 2004 by Preunkert et al. (2007) at Vallot. Legrand et al. (2002) estimated a mean halide $\mathrm{Cl}^{-}$contribution of $7 \mathrm{ppb}$ (on a total chloride of $10 \mathrm{ppb}$ ) and $10 \mathrm{ppb}$ (on a total chloride of $30 \mathrm{ppb}$ ) in winter and summer CDD snow and ice layers, respectively. The authors calculated a mean level of $\mathrm{Na}^{+}$(corrected from its leachable fraction from mineral dust) of $7 \mathrm{ppb}$ in summer and $4 \mathrm{ppb}$ in winter CDD snow and ice layers. These levels of sodium and chloride (corrected from the mineral dust contribution) suggest that sea salt aerosol would, at best, contribute $\sim 20$ ppb in CDD snow and ice layers. The chloride contribution from soils is considered in the following paragraph.

Given the low contribution of sea salt aerosol in the CDD snow deposits, it can be assumed that calcium is mainly related to mineral dust aerosol. The CDD calcium levels (after correction from Saharan dust, see Sect. 3.1) range from 40 to $80 \mathrm{ppb}$ in summer (Fig. 4) and from 5 to $15 \mathrm{ppb}$ in winter. A crude estimate of the total mass atmospheric concentration of mineral dust aerosol (including its chloride contribution) in Europe can be obtained by multiplying the calcium concentration by a factor of 4.5 (Putaud et al., 2004).

As discussed by Preunkert et al. (2001a), the fluoride content in CCD ice originates in soil dust aerosols and HF emitted from coal burning and release from aluminum smelters. In contrast to chloride the gas-aerosol partitioning of fluoride has not been documented in the atmosphere at the CDD site. However, given the low level of total fluoride observed in the ice (up to $3 \mathrm{ppb}$ on average in summer in the 1970s), 
Table 2. Mass concentrations in summer (S) and winter (W) CDK ice of various types of aerosol. The ways to calculate the mass of sea salt (from $\mathrm{Na}^{+}$and $\mathrm{Cl}^{-}$), dust (from $\mathrm{Ca}^{2+}$ ), and organic matter (OM) (from WSOC* and WinOC) are detailed in Sect. 4.

\begin{tabular}{|c|c|c|c|}
\hline Species (in ppb) & $1921-1951$ & $1971-1988$ & Enhancement factor \\
\hline Sea salt $S$ & 20 & 20 & 1 \\
\hline Sea salt W & 13 & 13 & 1 \\
\hline Dust $\mathrm{S}$ & 195 & 380 & 2 \\
\hline Dust W & 30 & 30 & 1 \\
\hline$\left(\mathrm{NH}_{4}^{+}\right.$and $\left.\mathrm{SO}_{4}^{2-}\right) \mathrm{S}$ & $204\left(254^{a}\right)$ & 830 & $4.1(3.3)$ \\
\hline$\left(\mathrm{NH}_{4}^{+}\right.$and $\left.\mathrm{SO}_{4}^{2-}\right) \mathrm{W}$ & 45 & 136 & 3 \\
\hline $\mathrm{OM}^{\left(\mathrm{WSOC}^{*}\right) \mathrm{S}}$ & 110 & 308 & 2.8 \\
\hline $\mathrm{OM}\left(\mathrm{WSOC}^{*}\right) \mathrm{W}$ & 54 & 113 & 2.1 \\
\hline $\mathrm{OM}$ (WinOC) $\mathrm{S}$ & 35 & 70 & 2 \\
\hline OM (WinOC) W & 35 & 35 & 1 \\
\hline $\mathrm{BC} \mathrm{S}$ & 6 & 14 & 2.3 \\
\hline $\mathrm{BC} \mathrm{W}$ & 6 & 6 & 1 \\
\hline
\end{tabular}

${ }^{\mathrm{a}}$ Denotes value accounting for the presence of particulate nitrate (see Sect. 4.1).

we neglected this species in the following calculations of the aerosol mass.

The respective contribution of the different types of inorganic aerosol (sea salt, mineral dust, and S- and N-derived aerosol) to the total aerosol load and their change from the period 1921-1951 to 1971-1988 are summarized in Table 2.

\subsection{Organics}

Until very recently, information on the load and composition of carbonaceous aerosol archived in ice remained very limited. Several studies have already investigated the long-term trend of elemental carbon (EC) or black carbon (BC) fraction in ice from various Alpine glaciers, such as the Mt Rosa (Lavanchy et al., 1999) and Fiescherhorn glaciers (Jenk et al., 2006) in Switzerland, but also in the C11 core of CDD (Legrand et al., 2007a). In the present-day European atmosphere, on a mass carbon basis, this fraction only accounts for $15 \%$ of carbonaceous aerosol (Pio et al., 2007). The reconstruction of past changes of the remaining part of carbonaceous aerosol (organic carbon, denoted OC) preserved in ice is a challenge since only the water-insoluble organic carbon (WinOC) fraction can be measured directly in ice, while the dissolved organic carbon (DOC) content measured in ice represents both the water-soluble organic carbon (WSOC) aerosol and water-soluble organic gases (Fig. 8). Similarly, the measurement of total organic carbon (TOC) content of ice also accounts for the presence of organic gases.

An extended array of organic species, including DOC, $\mathrm{C}_{1}-$ $\mathrm{C}_{3}$ monocarboxylates, $\mathrm{C}_{2}-\mathrm{C}_{5}$ dicarboxylates, formaldehyde, and for the first time HULIS, were recently investigated in the CDK ice cores (Legrand et al., 2013). The chemical speciation of the DOC content in CDK ice reported in Fig. 9 represents the unique case for which more than $50 \%$ of the DOC content in a hydrometeor is chemically identified. This percentage becomes even higher (67 to $73 \%$ ) in ice corre-
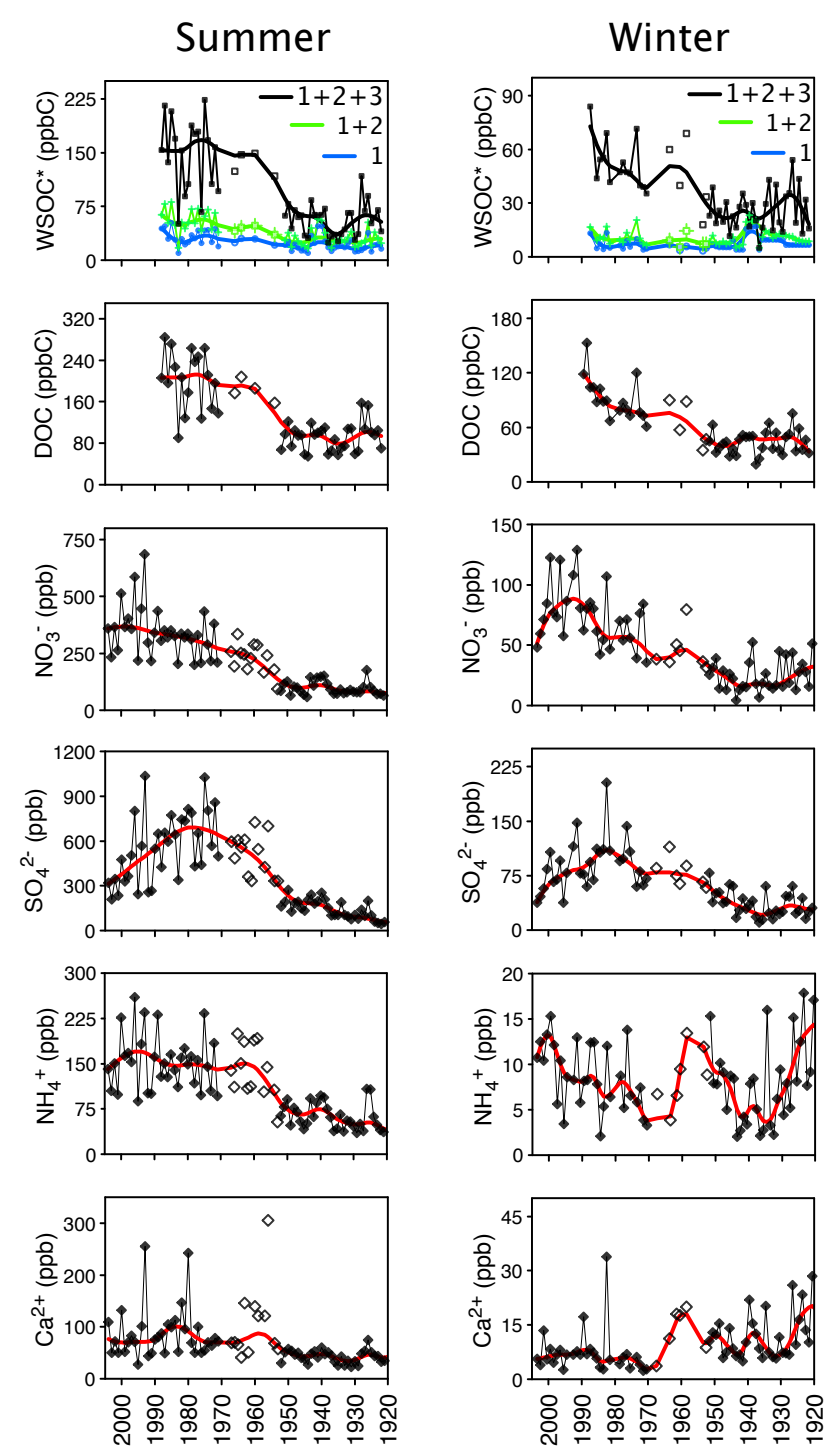

Fig. 7. Long-term trends extracted from summer (left) and winter (right) CDK snow and ice layers. From top to bottom: proxy of water-soluble organic carbon (WSOC*, see Sect. 4.2), dissolved organic carbon (DOC), nitrate, sulfate, ammonium, and calcium. On the WSOC* panel, the numbers 1,2 , and 3 refer to HULIS (blue line), the sum of HULIS and dicarboxylates (green line), and the sum of HULIS, dicarboxylates and an unknown fraction (black line) (see Sect. 4.2). For calcium, the Saharan dust events have been removed from the data. The solid symbols correspond to the well-dated part of the CDK ice core, the open symbols to samples from the $\mathrm{C} 11$ ice core (see Sect. 2.1). The thick solid lines are robust spline smoothings. Except for $\mathrm{NH}_{4}^{+}$and $\mathrm{Ca}^{2+}$, the panels are adapted from Legrand et al. (2013).

sponding to the first part of the 20th century (1921-1951). The extended knowledge of the chemical speciation of DOC was successfully explored to estimate the fraction that can be attributed to atmospheric WSOC aerosol. Among identified species that contribute to the DOC ice content (Fig. 9), 


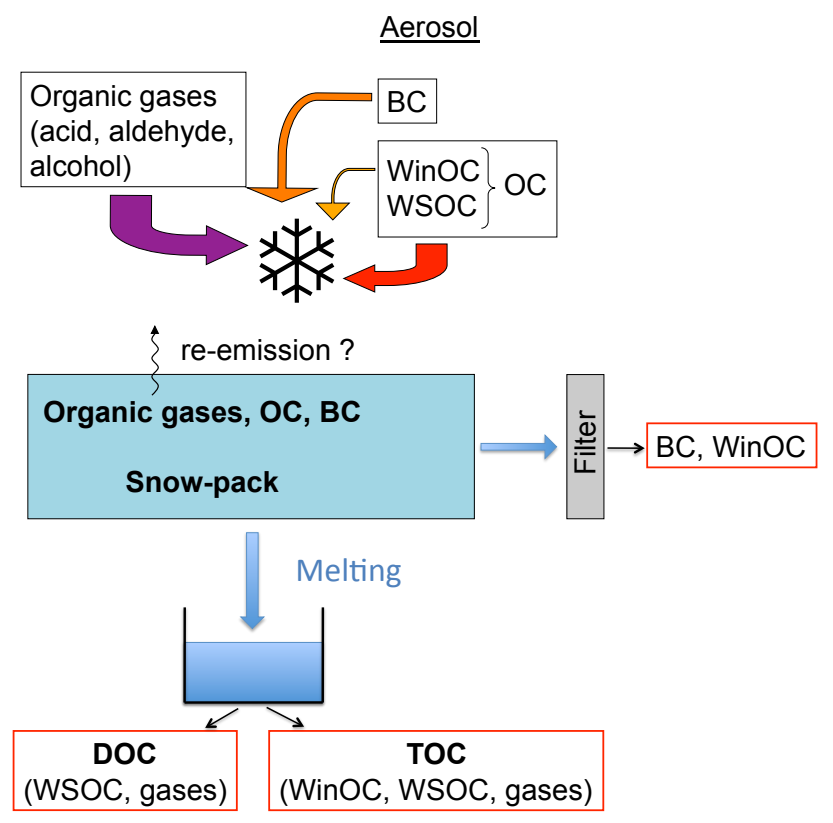

Fig. 8. The different atmospheric organic fractions trapped in ice. They include black carbon (BC), organic carbon (OC) and its two sub-fractions (water-soluble and water-insoluble organic carbon denoted WSOC and WinOC, respectively). DOC and TOC refer to dissolved and total organic carbon, respectively. Adapted from Legrand et al. (2013).

formaldehyde and $\mathrm{C}_{1}-\mathrm{C}_{3}$ monocarboxylic acids are organic gases that have been solubilized in precipitation, whereas $\mathrm{C}_{2}-\mathrm{C}_{5}$ dicarboxylic acids and HULIS represent a part of WSOC aerosol. From the examination of the atmospheric abundance and water-solubility of other short-chain organic gases having a polar character, Legrand et al. (2013) concluded that the determination of light monocarboxylic acids together with that of $\mathrm{HCHO}$ in ice have likely permitted quantifying most water-soluble organic gases contributing to the DOC content of ice. The unknown fraction of the DOC should therefore be mainly related to atmospheric WSOC aerosol, and the quantity denoted WSOC* ${ }^{*}$, calculated as the sum of HULIS, diacids and an unknown fraction in ice, would correspond to WSOC atmospheric aerosol. It has to be emphasized that in the European atmosphere WSOC aerosol generally dominates WinOC aerosol (Pio et al., 2007). In addition to carbon, organic aerosol contains in variable amounts hetero-atoms ( $\mathrm{H}, \mathrm{O}, \mathrm{N}$, etc.). To account for these atoms, a conversion factor has to be applied. The conversion factor is only known for chemically identified species. For instance, the mass conversion factor ranges from 3.7 for the $C_{2}$ diacid (oxalic acid) to 2.2 for the $\mathrm{C}_{5}$ diacid (glutaric acid). Though HULIS are a class of compounds (not a single species), a conversion factor close to 2.0 can be assumed. However, as seen in Fig. 9, most of the WSOC* ${ }^{*}$ carbon mass remains chemically unidentified, the unknown fraction accounting for $60 \%$ and $75 \%$ in ice deposited over the 1921-1951 and
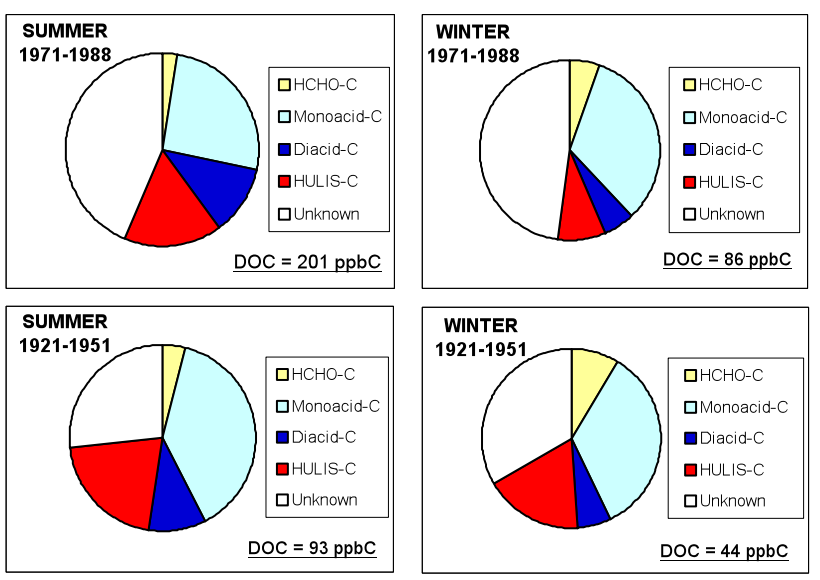

Fig. 9. Chemical composition of DOC present in winter and summer CDK ice layers corresponding to the first (1921-1951) and second (1971-1988) half of the 20th century. The identified organic species include formaldehyde, $\mathrm{C}_{1}-\mathrm{C}_{3}$ monocarboxylic (formic, lactic, acetic, glycolic, and glyoxylic) acids, $\mathrm{C}_{2}-\mathrm{C}_{5}$ dicarboxylic (oxalic, malic, malonic, succinic, and glutaric) acids, HULIS, and the unidentified fraction of DOC (see Sect. 4.2). Adapted from Legrand et al. (2013).

1971-1988 years, respectively. Therefore we have calculated the mass corresponding to WSOC* by using the mean mass conversion factor (2.1) estimated by Kiss et al. (2002) for the whole atmospheric WSOC aerosol.

Until now, the levels of $\mathrm{BC}$ and WinOC in CDD ice were only documented on discontinuous samples, 49 discontinuous summer ice samples and 5 winter samples selected along the C11 ice core (Legrand et al., 2007a). In summer, BC and WinOC levels slightly increase from the period 1921-1951 to $1971-1988$ (from 5 to $13 \mathrm{ppbC}$ and 25 to $50 \mathrm{ppbC}$, respectively). In winter, $\mathrm{BC}$ and WinOC levels remained close to 5 and $20 \mathrm{ppbC}$, respectively. Though further works are here clearly needed to document more continuously summer and winter layers, we made an attempt in Table 2 to calculate an order of magnitude of the contribution of these two carbonaceous components to the total aerosol mass. The mass conversion factor for BC would be close to 1.1 for this highly condensed aromatic structure (Kiss et al., 2002). For WinOC, we have assumed an intermediate conversion factor (1.4) lying between the BC and WSOC ones.

The respective contribution of the different types of carbonaceous aerosol (WSOC, WinOC, and EC) to the total aerosol load and their change between the periods 19211951 and 1971-1988 are summarized in Table 2. 


\section{Causes of aerosol-derived species changes in CDD ice deposited between 1920 and 1990}

As seen in Table 2, except sea salt, all other aerosol components exhibit a long-term trend in CDD ice. In this section, we briefly summarize the causes of observed changes that have already been discussed in previous works in addition to change of calcium, whose trend is discussed for the first time in the CDD ice cores.

Figures 2 and 7 show the key periods of the history of nitrogen and sulfur pollution over Europe. As already discussed by Preunkert et al. (2001b) on the basis of the C10 core, the regular increase of both summer and winter sulfate levels from 1925 to 1980 (a factor of 10 and 4, respectively) followed by a decrease resulting from improvements in the quality of fuel and emission abatements (Mylona, 1996) can be recognized in the CDD ice archives. Conversely, as discussed by Preunkert et al. (2003), the nitrate levels show a persistent increase (a factor of 4 in summer) until 1994.

Interestingly, the CDK ice core data reported in Fig. 7, which enlarge the covered time period with respect to the C10 core studies over more recent years, indicate that sulfate continues to decrease from 1994 to 2004 in agreement with a lasting reduction of $\mathrm{SO}_{2}$ emissions in western Europe until the beginning of the 21st century. In agreement with $\mathrm{SO}_{2}$ emissions from western Europe reported in Fig. 10, the recovered sulfate level in summer 2004 is close to the one observed in the early 1950s. On the other hand, nitrate ended up increasing only after 1995 (Fig. 7), consistent with the start of a slight decrease of NO emissions (Fig. 10). As shown in Fig. 7, the CDK ice record shows an increase by a factor of 3 of ammonium summer concentrations between 1940 and 1995. This record, which contrasts with the sulfate trend, is qualitatively in agreement with the historical $\mathrm{NH}_{3}$ emission trend (Fig. 10), but emissions increased only by a factor of two. As discussed by Fagerli et al. (2007), since the production of ammonium aerosol is limited by the availability of sulfuric and nitric acids, for which concentrations have increased more than the ammonia emissions up to 1980, a larger proportion of $\mathrm{NH}_{3}$ is converted to ammonium aerosols in 1980 than in 1925 . Finally, while $\mathrm{NH}_{3}$ emissions inventories do not yet report any decrease, the ammonium CDK record suggests a weak decrease after 2000. This may be related to a strong enough reduction of sulfuric acid leading to a decreasing production of ammonium aerosol.

The cause of the increase by a factor of 2 of calcium after 1950 (Fig. 7) may have several causes since, as pointed out by Putaud et al. (2004), this aerosol fraction includes all water-insoluble and non-carbonaceous components (e.g., soil dust, road dust, and fly ash). Man-made activities (road dust or agricultural activities for instance) or drier meteorological conditions may have contributed to this change of the background mineral dust atmospheric load in Europe. Further work is here clearly needed to better understand the causes of the observed calcium changes. For instance, stud-
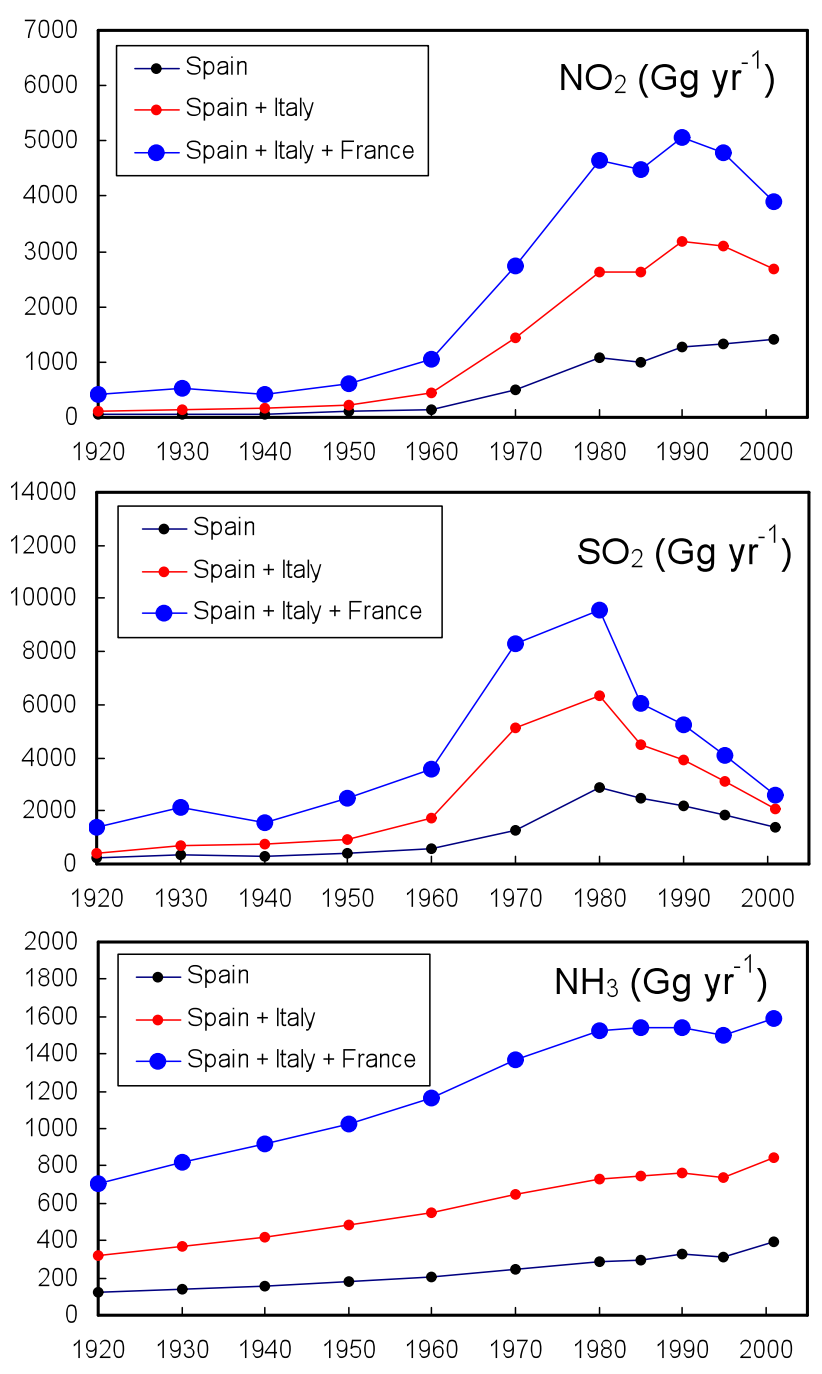

Fig. 10. Emissions of $\mathrm{NO}_{2}, \mathrm{SO}_{2}$, and $\mathrm{NH}_{3}$ from Spain, Italy, and France from 1920 to 2001. Adapted from Fagerli et al. (2007).

ies using trace elements and isotopes ( $\mathrm{Sr}$ and $\mathrm{Nd}$ for instance) would help to better decipher Saharan dust and background soil dust, road dust from natural soil weathering, etc.

The relative weak change of WinOC reported in Table 2 (a factor of 2 from 1930 to the 1970-1980s) is consistent with the finding from Jenk et al. (2006), who, on the basis of the fraction of modern carbon derived from ${ }^{14} \mathrm{C}$ analysis, reported a weak contribution of fossil fuel combustion to the WinOC levels. The WSOC* fraction increased by a factor of 3 and 2 from 1920 to 1990 in summer and winter, respectively (Fig. 7). The summer WSOC* change was highlighted by the ${ }^{14} \mathrm{C}$ signature of the DOC content of ice found by May et al. (2013). Examining the time lag of the $\mathrm{DO}^{14} \mathrm{C}$ in ice with the ${ }^{14} \mathrm{CO}_{2}$ around the bomb peak of 1965, the authors clearly concluded that the main biogenic source contributing to the DOC in ice in summer is the living biosphere, while biomass burning represents a very weak source. One of 
the major consequences of this result is that only $\sim 15 \%$ of the WSOC* increase is related to enhanced fossil fuel emissions, whereas $\sim 85 \%$ of the increase relate to the living biosphere (Legrand et al., 2013). There are many possible causes that may have strengthened either biogenic precursors of atmospheric WSOC (e.g., the temperature) or the gas-particle conversion rate (e.g., ozone concentrations). However, since a large part of the increase of $\mathrm{WSOC}^{*}$ in summer appears to be related to the chemically unidentified fraction (see Fig. 7), it remains difficult to discuss this summer trend in terms of possible involved gaseous precursors (isoprene, monoterpenes) emitted by vegetation. Finally, the change of BC by a factor of 2.3 (Table 2) in CDD ice deposited between 1930 and the 1970-1980s is consistent with the moderate change related to the decrease of coal burning in the residential sector which dominated total emissions until 1960 and the growing traffic emissions after 1950 (Fagerli et al., 2007).

\section{The changing aerosol load and composition over Europe from 1920 to 1990}

Based on discussions in Sect. 4, Table 2 summarizes the estimated mass concentrations of the different aerosols present in winter and summer CDD ice layers corresponding to the years 1921-1951 and 1971-1988. The total mass concentrations related to the different aerosol fractions together had increased by a factor of 2 in winter (from $183 \mathrm{ppb}$ in 19211951 to $333 \mathrm{ppb}$ in 1971-1988) and a factor of 3 in summer (from 570 ppb in 1921-1951 to $1622 \mathrm{ppb}$ in 1971-1988). A large part of these changes are due to the increase of ammonium and sulfate together with water-soluble organic matter (WSOM).

Though dominating the change of ice aerosol load, these ice core changes of ammonium, sulfate and water-soluble organic matter can nevertheless not be compared to those of other aerosol fractions like dust or water-insoluble organic matter in terms of atmospheric changes. Indeed, while for submicron water-soluble aerosols such as ammonium, sulfate and water-soluble organic matter we may expect a similar relationship between concentrations in air and snow, other aerosol fractions may have different relationships. For instance, other submicron aerosols - like water-insoluble organic matter or black carbon, being less water-soluble than the preceding components, or dust, having a super-micron contribution - would have different air-snow relationships compared to sulfate. Though the difference in the air-snow relationships for the different aerosol fractions is not accurately known, a better estimate of the past atmospheric change of aerosol load and composition can be derived by inverting the ice core concentrations to corresponding ambient air concentrations. Furthermore, by doing that we can also compare the inverted ice data that cover the years 1921-1951 and 1971-1988 with atmospheric data gained at the Vallot

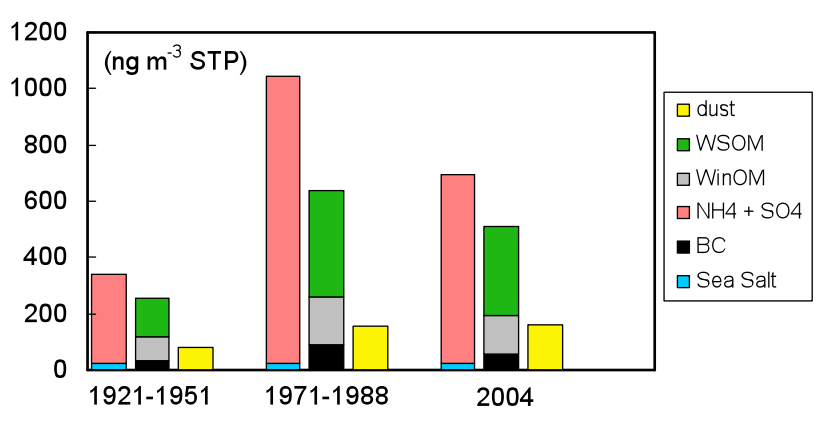

Fig. 11. Temporal changes of summer mass concentrations of different aerosols at the CDD site. For the 1921-1951 and 1971-1988 years, atmospheric concentrations were estimated by inverting ice concentrations (see Sect. 6), whereas the 2004 concentrations are data gained during a field atmospheric campaign conducted in summer 2004 (Legrand et al. 2007b; Preunkert et al., 2007).

site in summer 2004, a recent period over which DOC and WSOC snow deposit data are not available (see Sect. 2).

Preunkert et al. (2002) found that atmospheric sulfate levels of $800 \mathrm{ng} \mathrm{m}^{-3}$ STP in summer at the CDD site correspond to $650 \mathrm{ppb}$ in corresponding snow layers. These values were used to invert sulfate ice concentrations into atmospheric concentrations. A similar firn-air relationship was also used for other water-soluble submicron aerosols like ammonium aerosols and WSOC. For insoluble fractions like WinOC and $\mathrm{BC}$, a less efficient scavenging by precipitation is expected. Investigations made in air and precipitation at Sonnblick suggested that WinOC and BC are 2 and 5 times less efficiently removed from the atmosphere by snow than sulfate (Cerqueira et al., 2010). On this basis, we have multiplied the ice levels of WinOC by a factor of 2 and those of $\mathrm{BC}$ by a factor of 5 to account for the less efficient incorporation in precipitation prior to applying the preceding firn-air relationship.

Though not yet documented, the size of sea salt aerosol at the top of the Alps would be larger than the preceding submicron aerosols. For this aerosol component, we still have applied the same firn-air relationship to invert ice core sea salt content. Note that, even though uncertain, given the low abundance of this aerosol fraction, the results will not modify the overall obtained composition of aerosol. Concerning calcium, it would lead to erroneous calculations to invert dust ice concentrations with a similar firn-air relationship to the one used for preceding species. Indeed, Puxbaum and Tscherwenka (1998) showed that the ratio of calcium present in snow and rime at Sonnblick is far higher than for sulfate ( 0.5 instead of 0.2). This calcium enrichment in the ice phase suggests that in contrast to sulfate, mainly present in rime, dust aerosol can be scavenged by ice crystals (the mineral aerosol might act as ice condensation nuclei). Preunkert and Wagenbach (1998) reported a firn-air relationship some 6 times higher for calcium than for sulfate at Colle Gnifetti. 
With a mean calcium level of $35 \mathrm{ng} \mathrm{m}^{-3}$ STP in aerosol collected at Vallot in summer since 1999 (see Sect. 4.1), the mean calcium concentration in summer snow of around $75 \mathrm{ppb}$ (Fig. 4) indicates also a better scavenging of calcium with respect to sulfate by a factor of 3 . The dust contribution was calculated by assuming that this aerosol is three times more efficiency scavenged by snow than sulfate and WSOC.

The inverted summer ice concentrations corresponding to the years 1921-1951 and 1971-1988 are compared in Fig. 11 with atmospheric observations made in summer 2004 at the Vallot observatory. As already mentioned in Sect. 4.1, during this campaign, sulfate, ammonium, and particulate nitrate were documented (Preunkert et al., 2007). A mean calcium level of $36 \mathrm{ng} \mathrm{m}^{-3}$ STP was observed (unpublished data). The different carbonaceous aerosol fractions were also measured, showing concentrations of 50,100 , and $150 \mathrm{ngC} \mathrm{m}^{-3}$ STP for BC, WinOC, and WSOC, respectively (Legrand et al., 2007b). In Fig. 11, the dust fraction is considered separately from the other inorganic fraction since this aerosol fraction would stay in the coarse size range. Indeed, it was shown that background crustal aerosol at Colle Gnifetti exhibits a diameter close to 2.5 microns (Wagenbach and Geis, 1989).

Figure 11 shows that, in addition to an increase by a factor of 2 of the coarse dust aerosol from 1920 to present day, load and composition of submicron aerosols in summer have changed over time. From 1921-1951 to 1971-1988, the atmospheric load of submicron aerosol has been enhanced by a factor of 3 mainly due to the large change of $\mathrm{N}$ - and S-derived aerosols and WSOM. Compared to the situation encountered over the 1971-1988 years, the submicron aerosol load redecreased in 2004 mainly in relation to the strong decrease of sulfate (a factor of 2), whereas $\mathrm{N}$-derived aerosol and WSOM remained quasi unchanged. Whereas the observed long-term trend of ammonium, nitrate, and sulfate are in very good agreement with our knowledge of growing emissions of $\mathrm{NH}_{3}, \mathrm{NO}_{\mathrm{x}}$, and $\mathrm{SO}_{2}$, the change of WSOM needs further investigations. Indeed, though clearly attributed to the biosphere by $\mathrm{DO}^{14} \mathrm{C}$ measurements, its chemical speciation is still too poorly documented to identify the precursors (isoprene, monoterpenes) and thus the causes of the increase.

\section{Conclusions}

From seasonally resolved chemical ice core records extracted from the high-elevation Alpine site of the Col du Dôme glacier, relevant chemical parameters were used to reconstruct past change of atmospheric aerosol load and composition over Europe from 1920 to present. The extended array of investigated inorganic $\left(\mathrm{Na}^{+}, \mathrm{Ca}^{2+}, \mathrm{NH}_{4}^{+}, \mathrm{Cl}^{-}, \mathrm{NO}_{3}^{-}\right.$, and $\mathrm{SO}_{4}^{2-}$ ) and organic (carboxylates, $\mathrm{HCHO}$, humic-like substances, dissolved organic carbon, water-insoluble organic carbon, and black carbon) compounds and fractions permit examining the key aerosol components (sea salt, min- eral dust, nitrogen- and sulfur-related aerosol, and carbonaceous aerosol). It is shown that coarse aerosol related to background mineral dust and possibly also of Saharan dust events have increased by a factor of around two. The total load of submicron aerosol has increased by a factor of 3 from the 1921-1951 to 1971-1988 years, mainly as a result of a large increase of sulfate (a factor of 5), ammonium and watersoluble organic matter (a factor of 3). Whereas a strong reduction of sulfate had occurred after the 1980s, the level of nitrogen-derived aerosol and water-soluble organic matter remains in the present-day atmosphere almost as high as in the 1980s. Therefore, not only inorganic pollution by $\mathrm{NH}_{3}, \mathrm{SO}_{2}$, and $\mathrm{NO}_{\mathrm{x}}$ have led to enhanced atmospheric aerosol load over Europe but also biogenic emissions of precursors of watersoluble organic matter that have increased since 1950. This rather unexpected change of biospheric emissions would motivate further atmospheric and ice core studies to highlight possible causes of these change of natural emissions. Finally, further work is needed to better understand the causes of calcium changes.

Acknowledgements. Funding was provided by the European Community via contracts ENV4-CT97 (ALPCLIM) and ENV4CT96-5051 (Environment and Climate Research Training), and by the Ministry for Science and Research of Baden-Württemberg within the collaboration program between Region Rhône-Alpes and Baden-Württemberg. The drilling operation to extract the CDK ice core at Col du Dôme was supported by the EU CARBOSOL project (contract EVK2 CT2001-00113). Finally the study of organics in the CDK ice cores was funded by the CNRS-DFG bilateral project entitled "Secondary organic aerosol production in the lower free troposphere over western Europe". We would like to thank Dietmar Wagenbach from IUP Heidelberg for continuous steering activities and a close and fruitful collaboration through these Alpine ice core studies that started more than 30 years ago.

Edited by: G. Winckler

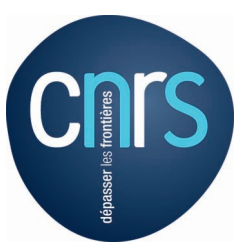

The publication of this article is financed by CNRS-INSU.

\section{References}

Baltensperger, U., Gaeggeler, H. W., Jost, D. T., Lugauer, M., Schwikowski, M., Weingartner, E., and Seibert, P.: Aerosol climatology at the high-alpine site Jungfraujoch, Switzerland, J. Geophys. Res., 102, 19707-19715, 1997.

Bloomfield, P. and Steiger, W. L.: Last Absolute Deviations: Theory, Applications and Algorithms, Birkhäuser Boston, Cambridge, Mass, 1983.

Cerqueira, M., Pio, C., Legrand, M., Puxbaum, H., KasperGiebl, A., Afonso, J., Preunkert, S., Gelencsér, A., 
and Fialho, P.:Particulate carbon in precipitation at European background sites, J. Aerosol Sci., 41, 51-61, doi:10.1016/j.jaerosci.2009.08.002, 2010.

Dibb, J., Talbot, R. W., Scheuer, E. M., Seid, G., Avery, M. A., and Singh, H. B.: Aerosol composition in Asian continental outflow during the TRACE-P campaign: Comparison with PEM-West B, J. Geophys. Res., 108, 8815, doi:10.1029/2002JD003111, 2003.

Fagerli, H., Legrand, M., Preunkert, S., Vestreng, V., Simpson, D., and Cerqueira, M.: Modeling historical long-term trends of sulfate, ammonium, and elemental carbon over Europe: A comparison with ice core records in the Alps, J. Geophys. Res., 112, D23S13, doi:10.1029/2006JD008044, 2007.

Guilhermet, J., Preunkert, S., Voisin, D., Baduel, C., and Legrand, M.: Major 20th century changes of water-soluble HUmic LIke Substances (HULISWS) aerosol over Europe inferred from Alpine ice cores, J. Geophys. Res., 118, 3869-3878, doi:10.1002/jgrd.50201, 2013.

Hammer, S., Wagenbach, D., Preunkert, S., Pio, C., Schlosser, C., and Meinhardt, F.: Lead-210 observations within CARBOSOL: A diagnostic tool for assessing the spatiotemporal variability of related chemical aerosol species?, J. Geophys. Res., 112, D23S03, doi:10.1029/2006JD008065, 2007.

Hering, S. and Cass, G.: The magnitude of bias in the measurement of PM2.5 arising from volatilisation of particulate nitrate from Teflon filters, J. Air Waste Manage., 49, 725-733, 1999.

Jenk, T. M., Szidat, S., Schwikowski, M., Gäggeler, H. W., Brütsch, S., Wacker, L., Synal, H.-A., and Saurer, M.: Radiocarbon analysis in an Alpine ice core: record of anthropogenic and biogenic contributions to carbonaceous aerosols in the past (1650-1940), Atmos. Chem. Phys., 6, 5381-5390, doi:10.5194/acp-6-53812006, 2006.

Kasper, A. and Puxbaum, H.: Seasonal variation of $\mathrm{SO}_{2}$, $\mathrm{HNO}_{3}, \mathrm{NH}_{3}$ and selected aerosol components at Sonnblick (3106 m a.s.1.), Atmos. Envorin., 32, 3925-3939, 1998.

Kiss, G., Varga, B., Galambos, I., and Ganszky, I.: Characterization of water-soluble organic matter isolated from atmospheric fine aerosol, J. Geophys. Res., 107, 8339, doi:10.1029/2001JD000603, 2002.

Lavanchy, V. M. H., Gäggeler, H. W., Schotterer, U., Schwikowski, M., and Baltensperger U.: Historical record of carbonaceous particle concentrations from a European high-alpine glacier (Colle Gnifetti, Switzerland), J. Geophys. Res., 104, 21227-21236, 1999.

Legrand, M. and Mayewski, P.: Glaciochemistry of polar ice cores: A review, Rev. Geophys., 35, 219-243, 1997.

Legrand, M., Preunkert, S., Wagenbach, D., and Fischer, H.: Seasonally resolved Alpine and Greenland ice core records of anthropogenic $\mathrm{HCl}$ Emissions over the 20th century, J. Geophys. Res., 107, 4139, doi:10.1029/2001JD001165, 2002.

Legrand, M., Preunkert, S., Wagenbach, D., Cachier, H., and Puxbaum, H.: A historical record of formate and acetate from a high elevation Alpine glacier: Implications for their natural versus anthropogenic budgets at the European scale, J. Geophys. Res., 108, 4788, doi:10.1029/2003JD003594, 2003.

Legrand, M., Preunkert, S., Galy-Lacaux, C., Liousse, C., and Wagenbach, D.: Atmospheric year-round records of dicarboxylic acids and sulfate at three French sites located between 630 and $4360 \mathrm{~m}$ elevation, J. Geophys. Res., 110, D13302, doi:10.1029/2004JD005515, 2005.
Legrand, M., Preunkert, S., Schock, M., Cerqueira, M., KasperGiebl, A., Afonso, J., Pio, C., Gelencsér, A., and DombrowskiEtchevers, I.: Major 20th century changes of carbonaceous aerosol components (EC, WinOC, DOC, HULIS, carboxylic acids, and cellulose) derived from Alpine ice cores, J. Geophys. Res., 112, D23S11, doi:10.1029/2006JD008080, 2007a.

Legrand, M., Preunkert, S., Oliveira, T., Pio, C. A., Hammer, S., Gelencsér, A., Kasper-Giebl, A., and Laj, P.: Origin of $\mathrm{C}_{2}-\mathrm{C}_{5}$ dicarboxylic acids in the European atmosphere inferred from yearround aerosol study conducted at a west-east transect, J. Geophys. Res., 112, D23S07, doi:10.1029/2006JD008019, 2007 b.

Legrand, M., Preunkert, S., May, B., Guilhermet, J., Hoffmann, H., and Wagenbach, D.: Major 20th century changes of the content and chemical speciation of organic carbon archived in Alpine ice cores: implications for the long-term change of organic aerosol over Europe, J. Geophys. Res., 118, 3879-3890, doi:10.1002/jgrd.50202, 2013.

Maupetit, F. and Delmas, R. J.: Snow chemistry of high altitude glaciers in the French Alps, Tellus B, 46, 304-324, 1994.

May, B., Wagenbach, D., Hoffmann, H., Legrand, M., Preunkert, S., and Steier, P.: Constraints on the major sources of dissolved organic carbon in Alpine ice cores from Radiocarbon analysis over the bomb peak period, J. Geophys. Res., 118, 3319-3327, doi:10.1002/jgrd.50200, 2013.

Mylona, S.: Sulfur dioxide emissions in Europe 1880-1991, and their effect on sulphur concentrations and deposition, Tellus B, 48, 662-689, 1996.

Pio, C. A., Legrand, M., Oliveira, T., Afonso, J., Santos, C., Caseiro, A., Fialho, P., Barata, F., Puxbaum, H., Sanchez-Ochao, A., Kasper-Giebl, A., Gelencsér, A., Preunkert, S., Schock, M.: Climatology of aerosol composition (organic versus inorganic) at non-urban sites on a west-east transect across Europe, J. Geophys. Res., 112, D23S02, doi:10.1029/2006JD008038, 2007.

Preunkert, S.: L'histoire de la pollution atmosphérique Européenne reconstituée à partir des carottes de glace Alpine, Ph. D. thesis, 240 pp., Univ. Joseph Fourier de Grenoble, France, 2001.

Preunkert, S. and Wagenbach, D.: An automatic recorder for air/firn transfer studies of chemical aerosol species at remote glacier sites, Atmos. Environ., 32, 4021-4030, 1998.

Preunkert, S., Wagenbach, D., Legrand, M., and Vincent, C.: Col du Dôme (Mt Blanc Massif, French Alps) suitability for ice core studies in relation with past atmospheric chemistry over Europe, Tellus, 59, 993-1012, 2000.

Preunkert, S., Legrand, M., and Wagenbach, D.: Causes of enhanced fluoride levels in Alpine ice cores over the last 75 years: Implications for the atmospheric fluoride budget, J. Geophys. Res., 106, 12619-12632, 2001a.

Preunkert, S., Legrand, M., and Wagenbach, D.: Sulfate trends in a Col du Dôme (French Alps) ice core: A record of anthropogenic sulfate levels in the European mid-troposphere over the 20th century, J. Geophys. Res., 106, 31991-32004, 2001 b.

Preunkert, S., Wagenbach, D., and Legrand, M.: Improvement and characterization of an automatic aerosol sampler at high-Alpine drilling sites, Atmos. Environ., 36, 1221-1232, 2002.

Preunkert, S., Wagenbach, D., and Legrand, M.: A seasonally resolved Alpine ice core Record of Nitrate: Comparison with Anthropogenic Inventories and estimation of Pre-Industrial Emissions of NO from Europe, J. Geophys. Res., 108, 4681, doi:10.1029/2003JD003475, 2003. 
Preunkert, S., Legrand, M., Jourdain, B., and DombrowskiEtchevers, I.: Acidic gases $\left(\mathrm{HCOOH}, \mathrm{CH}_{3} \mathrm{COOH}, \mathrm{HNO}_{3}, \mathrm{HCl}\right.$, and $\mathrm{SO}_{2}$ ) and related aerosol species at a high mountain Alpine site (4360 m elevation) in Europe, J. Geophys. Res., 112, D23S12, doi:10.1029/2006JD008225, 2007.

Preunkert, S., Legrand, M., Stricker, P., Bulat, S., Alekhina, I., Petit, J. R., Hoffmann, H., May, B., and Jourdain, B.: Quantification of Dissolved Organic Carbon at very low levels in natural ice samples by a UV induced oxidation method, Environ. Sci. Technol., 45, 673-678, 2011.

Putaud, J.-P., Raes, F., Van Dingenen, R., Brüggemann, E., Facchini, M.-C., Decesari, S., Fuzzi, S., Gehrig, R., Hüglin, C., Laj, P., Lorbeer, G., Maenhaut, W., Mihalopoulos, N., Müller, K., Querol, X., Rodriguez, S., Schneider, J., Spindler, G., ten Brink, H., Tørseth, K., and Wiedensohler, A.: A European aerosol phenomenology 2: Chemical characteristics of particulate matter at kerbside, urban, rural and background sites in Europe, Atmos. Environ., 38, 2579-2595, 2004.
Puxbaum, H. and Tscherwenka, W.: Relationship of major ions in snow fall and rime at Sonnblick observatoty (SBO, $3106 \mathrm{~m}$ ) and implications for scavenging processes in mixed clouds, Atmos. Environ., 32, 4011-4020, 1998.

Wagenbach, D. and Geis, K.: The mineral dust record in a high altitude Alpine glacier (Colle Gnifetti, Swiss Alps), in: Paleoclimatology and Paleometeorology: Modern and Past Patterns of Global Atmospheric Transport, edited by: Leinen, M. and Sarnthein, M., Kluwer Academic Press, Dordrecht, NL, 1989.

Wagenbach, D., Preunkert, S., Schaefer, J., Jung, W., and Tomadin, L.: Northward transport of Saharan dust recorded in a deep Alpine ice core, in: The impact of African dust across the Mediterranean, edited by: Guerzoni, S. and Chester, R., Kluwer Academic Publishers, The Neetherlands, 291-300, 1996.

Wagenbach, D., Bohleber, P., and Preunkert, S.: Cold, Alpine ice bodies revisited: What may we learn from their impurity and isotope content?, Geogr. Ann. A, 94, 245-263, doi:10.1111/j.14680459.2012.00461.x, 2012. 